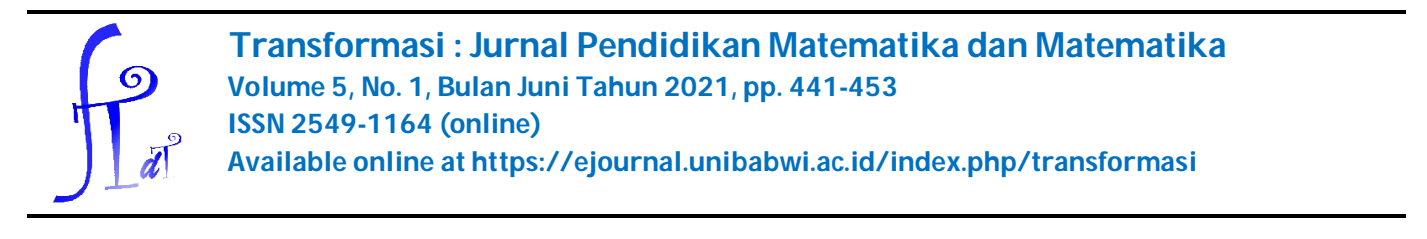

\title{
PENGEMBANGAN LKPD DENGAN MODEL PEMBELAJARAN MISSOURI MATHEMATICS PROJECT UNTUK PEMBELAJARAN ONLINE
}

\author{
Rifatul Hidayah ${ }^{1}$, Siska Candra Ningsih ${ }^{2}$ \\ 1,2Fakultas Keguruan dan Ilmu Pendidikan, Universitas PGRI Yogyakarta \\ E-mail koresponden: siska@upy.ac.id
}

Diterima : (13-11-2020), Revisi: (06-05-2021), Diterbitkan : (20-05-2021)

\begin{abstract}
ABSTRAK
Penelitian ini merupakan penelitian pengembangan yang bertujuan untuk menghasilkan Lembar Kegiatan Peserta Didik (LKPD) menggunakan model pembelajaran Missouri Mathematics Project (MMP) yang dapat digunakan dalam pembelajaran online. LKPD yang dikembangkan juga untuk memfasilitasi kemampuan pemahaman konsep peserta didik kelas VIII semester II. Model pengembangan yang digunakan adalah model pengembangan ADDIE dengan 5 tahapan yaitu: analisis, desain, pengembangan, implementasi dan evaluasi. Hasil penelitian menunjukkan bahwa Lembar Kegiatan Peserta Didik (LKPD) yang dikembangkan memenuhi kriteria valid, praktis dan efektif. Kualitas LKPD dinyatakan valid oleh ahli materi dan ahli media dengan skor 3.31. Berdasarkan angket kepraktisan, LKPD dinyatakan praktis dengan skor 3.57. Efektivitas LKPD ditinjau dari hasil tes pemahaman konsep matematika per indikator.
\end{abstract}

Kata Kunci: LKPD, Missouri Mathematics Project (MMP), pemahaman konsep.

\begin{abstract}
This research is a Research and Development which aims to produce a Student Work Sheet using the Missouri Mathematics Project (MMP) learning model. Student Worksheet can use in elearning. Student Worksheet also to facilitate the ability to understand the concepts of VIII grade II semester II students. The development model used is the ADDIE development model with 5 stages: analysis, design, development, implementation and evaluation. The results showed that the Student Worksheet was produced that met the valid, practical and effective criteria. Student Worksheet quality is declared valid by material experts and media experts with a score of 3.31. Based on data declared practical with a score of 3.57. The effectiveness of Student Worksheet is reviewed from the results of the understanding of mathematical test.
\end{abstract}

Keywords: Student Worksheet, Missouri Mathematics Project, understanding concept. 


\section{Pendahuluan}

Coronavirus Disease 2019 (COVID-19) telah melanda negara-negara di dunia termasuk Indonesia. Covid-19 pertama di Indonesia dilaporkan pada tanggal 2 Maret 2020. Sejak saat itu Covid-19 terus menyebar hingga saat ini. Virus ini terus menular dari manusia ke manusia dengan sangat cepat dan telah menjadi pandemi sehingga perlu diwaspadai (Susilo et al., 2020). Pandemi ini memberikan dampak pada berbagai bidang kehidupan termasuk pendidikan. Pada tanggal 24 Maret 2020 Menteri Pendidikan dan Kebudayaan Republik Indonesia telah mengeluarkan surat edaran tentang pelaksanaan kebijakan pendidikan dalam masa darurat penyebaran covid-19. Proses belajar mengajar dilaksanakan dari rumah melalui pembelajaran daring atau pembelajaran jarak jauh (Surat Edaran Nomor 4 Tahun 2020 Tentang Pelaksanaan Kebijakan Pendidikan Dalam Masa Darurat Penyebaran Coronavirus Disease (Covid-19), 2020). Menindaklanjuti edaran ini maka perlu dilakukan berbagai inovasi dalam pembelajaran. Sebagaimana disampaikan Sun, Tang, \& Zuo (2020) wabah covid 19 mendesak dilakukannya berbagai pengembangan dan penelitian secara serentak bagi semua elemen pendidikan.

Pembelajaran daring atau pembelajaran online diterapkan kepada peserta didik mulai tingkat Pendidikan Anak Usia Dini hingga Perguruan Tinggi. Pembelajaran online merupakan proses transfer ilmu yang dilakukan menggunakan gambar, teks, audio, video dan peragkat lunak (Herliandry, et.al., 2020). Menurut Sadikin \& Hamidah (2020) pembelajaran online efektif dilakukan karena memungkinkan pendidik dan peserta didik melakukan interaksi dalam kelas virtual yang dapat dilakukan dimana saja dan kapan saja. Namun pembelajaran secara online tentu juga memiliki berbagai tantangan baik dari aspek sumber daya manusia, sarana dan prasarana serta teknik implementasi (Wahyono, Husamah, \& Budi, 2020). Komunikasi antara peserta didik dengan pendidik tidak selamanya dapat berjalan dengan baik. Peserta didik mengalami kesulitan dalam memahami materi pelajaran yang diberikan oleh pendidik. Pembelajaran online yang dilaksanakan saat ini baru sebatas transfer pengetahuan dari pendidik kepada peserta didik sehingga pemahaman peserta didik terhadap materi yang dipelajari sangat kurang (Saefulmulah \& Saway, 2020; Firdaus, 2020). Pendidik juga tidak dapat mengontrol aktivitas dan kemampuan peserta didiknya. Pendidik hanya menerima hasil akhir dari setiap tugas yang diberikan kepada siswa (Anugrahana, 2020).

Kondisi seperti ini tentu saja tidak dapat dibiarkan begitu saja. Pembelajaran yang dilaksanakan harus tetap mencapai kompetensi yang diinginkan. Menurut Widodo (2017) untuk mencapai kompetensi tersebut bahan ajar yang digunakan harus disertai dengan Lembar Kegiatan Peserta Didik (LKPD), karena LKPD berisi 
semua aktivitas peserta didik dalam pembelajaran. Melalui LKPD pendidik dapat mengamati proses dan keberhasilan seorang peserta didik dalam mencapi kompetensi pembelajaran. LKPD dapat menjadi sarana interaksi aktif antara peserta didik dan pendidik (Umbaryati, 2016). LKPD dalam pembelajaran tatap muka telah banyak digunakan di sekolah khususnya untuk pelajaran matematika. Namun LKPD yang digunakan masih membutuhkan bimbingan langsung dari pendidik. LKPD dalam pembelajaran langsung juga masih berupa ringkasan materi dan latihan soal sehingga peserta didik cenderung menghafal latihan soal tanpa memahami konsepnya. Hal ini kurang cocok untuk pembelajaran online. LKPD dapat dirancang sesuai dengan situasi pembelajaran. LKPD berisi tugas-tugas yang harus diselesaikan peserta didik yang disertai dengan petunjuk dan langkah-langkah kegiatan untuk menyelesaikan tugas sehingga peserta didik dapat menyelesaikan tugasnya secara mandiri.

Pemilihan model pembelajaran yang tepat dapat meningkatkan aktivitas dan keberhasilan belajar peserta didik (Basori, 2014). Model pembelajaran Missouri Mathematics Project (MMP) merupakan salah satu model pembelajaran yang menuntut peserta didik untuk berperan aktif dalam pembelajaran. Fauziah \& Sukasno (2015) menyatakan bahwa model pembelajaran MMP menuntut peserta didik untuk bekerja dalam kelompok dan mengiplementasikan pemahamannya dalam kerja mandiri. Model Pembelajaran MMP yang terdiri dari tahapan pendahuluan (review), pengembangan (development), kerja kooperatif (team),kerja m,andiri (seatwork), dan penutup (cover) menuntut peserta didik aktif dalam pembelajaran untuk menemukan pengetahuan dengan guru sebagai fasilitator (Tiasto \& Arliani, 2015; Dewi, Jaya, \& Rahmawati, 2019).

Wahyuni, Efuansyah, \& Sukasno (2020) telah mengembangkan LKPD dengan model Missouri Mathematics Project dengan strategi Think Talk Write. Aufa, Zubainur, \& Munzir (2021) juga telah mengembangkan perangkat pembelajaran yang di dalamnya termasuk LKPD dengan bantuan software Geogebra. LKPD yang telah dikembangkan tersebut masih terbatas untuk menunjang proses pembelajaran langsung. Berdasarkan hal di atas maka perlu dikembangkan LKPD dengan model pembelajaran Missouri Mathematics Project yang dapat digunakan dalam pembelajaran online.

\section{Metode Penelitian}

Penelitian ini merupakan penelitian pengembangan. Model pengembangan yang digunakan dalam penelitian ini adalah model pengembangan ADDIE, yang terdiri dari lima langkah, yaitu analisis (analysis), desain (design), pengembangan (devel- 
opment), implementasi (implementation), dan evaluasi (evaluation)(Ningsih \& Sunanti, 2020). Penelitian dilaksanakan di SMPN 3 Jetis Yogyakarta dengan subjek penelitian Kelas VIII B yang terdiri dari 26 peserta didik dan kelas VIII D sebanyak 30 peserta didik.

Teknik pengumpulan data yang digunakan dalam penelitian ini adalah angket dan tes. Instrumen pengumpulan data yang digunakan pada penelitian ini ada 3 macam, yaitu instrumen untuk menilai kevalidan LKPD berupa angket yang diisi oleh ahli materi dan ahli bahan ajar. Instrumen untuk menilai kepraktisan digunakan angket kepraktisan yang diisi oleh guru dan peserta didik yang telah menggunakan LKPD. Sedangkan instrumen untuk menilai keefektifan LKPD yang dikembangkan digunakan tes kemampuan pemecahan masalah.

Teknik analisis data dalam penelitian ini dapat dibedakan menjadi dua macam. Data angket dianalisis menggunakan langkah-langkah: (1) memberikan penskoran pada angket, dan (2) menghitung jumlah dan rata-rata setiap aspek dengan rumus sebagai berikut : $\bar{X}=\frac{\sum x}{n}$

Dengan $\quad: \quad \bar{X} \quad$ : Skor rata-rata masing-masing aspek

$\sum x \quad$ :Jumlah keseluruhan skor masing-masing aspek

$n \quad$ : Banyaknya butir pernyataan tiap aspek

Data tes pada penelitian ini dianalisis dengan langkah-langkah berikut ini :

1. Tentukan skor tiap indikator pada masing-masing butir soal dengan acuan pedoman penskoran yang telah ditetapkan.

2. Jumlahkan skor tiap indikator pemahaman konsep untuk setiap butir soal.

3. Hitung rata-rata indikator pemahaman konsep dengan menggunakan rumus :

$$
n=\frac{\text { Skor yang diperoleh }}{\text { Skor maksimal }} \times 100
$$

Dengan $\mathrm{n}$ : Jumlah skor

Setelah mendapatkan skor rata-rata tiap aspek baik pada angket maupun tes dinyatakan dalam nilai kualitatif dengan cara membandingkannya dengan kriteria penilaian tertentu. Kriteria yang digunakan disajikan dalam tabel berikut.

Tabel 1. Kriteria Angket Angket Respon Peserta Didik dan Pendidik

\begin{tabular}{cc}
\hline Interval Skor & Kriteria \\
\hline $\bar{X}>\bar{X}_{l}+1,8 \times s b_{i}$ & Sangat baik \\
$\left(\bar{X}_{l}+0,6 \times s b_{i}\right)<\bar{X} \leq\left(\bar{X}_{l}+1,8 \times s b_{i}\right)$ & Baik \\
$\left(\bar{X}_{l}-0,6 \times s b_{i}\right)<\bar{X} \leq\left(\bar{X}_{l}+0,6 \times s b_{i}\right)$ & Cukup \\
$\left(\bar{X}_{l}-1,8 \times s b_{i}\right)<\bar{X} \leq\left(\bar{X}_{l}-1,8 \times s b_{i}\right)$ & Kurang \\
$\bar{X} \leq \bar{X}_{l}-1,8 \times s b_{i}$ & Sangat Kurang \\
\hline
\end{tabular}

(Widyoko, 2015) 
Dengan ketentuan sebagai berikut :

$$
\begin{aligned}
& X \quad \text { Skor empiris } \\
& X_{i}: \text { Rerata ideal }=\frac{1}{2}(\text { skor maksimal ideal }+ \text { skor minimal ideal }) \\
& s b_{i}: \text { Simpangan Baku Ideal }=\frac{1}{6}(\text { skor maksimal ideal }+ \text { skor minimal ideal })
\end{aligned}
$$

\section{Hasil dan Pembahasan}

LKPD dengan model pembelajaran MMP dikembangkan untuk materi bangun ruang sisi datar kubus dan balok di kelas VIII SMP. LKPD dirancang dengan memenuhi syarat minimal unsur-unsur LPKD yang dinyatakan oleh Widodo (2017) yaitu judul, petunjuk belajar, kompetensi dasar atau materi pokok, informasi pendukung, tugas atau langkah kerja, dan penilaian.

\section{Tahap analisis (Analysis)}

\section{Analisis Kebutuhan}

Pada tahap ini dilakukan observasi ke sekolah dan wawancara dengan pendidik mata pelajaran matematika. Dari kegiatan ini diperoleh informasi bahwa LKPD yang digunakan selama ini merupakan LKPD yang biasa digunakan dalam pembelajaran langsung. LKPD tersebut kurang menunjang pembelajaran online karena kurangnya informasi dan petujuk kegiatan yang diberikan didalamnya. Oleh karena itu perlu dikembangkan LKPD yang berisi kegiatan-kegiatan yang dapat melibatkan peserta didik dalam kegiatan pembelajaran secara aktif sehingga dapat menambah pengetahuan, pemahaman konsep, dan pengalaman belajar peserta didik. LKPD yang dikembangkan dapat digunakan bukan hanya dalam pembelajaran langsung tetapi juga dalam pembelajaran online sesuai dengan kebutuhan pembelajaran saat ini. Sejalan dengan pendapat Devita yohanie \& Samijo (2019) bahwa dalam pembelajaran diperlukan sebuah sumber belajar yang dapat dimanfaatkan oleh peserta didik secara optimal.

\section{Analisis Kurikulum}

Kurikulum yang digunakan adalah kurikulum 2013. Hasil analisis kurikulum adalah penjabaran dari kompetensi dasar $(\mathrm{KD})$ dan indikator pencapaian yang mengacu pada kegiatan pembelajaran. LKPD yang dikembangkan membahas materi bangun ruang sisi datar kubus dan balok.

\section{Tahap Desain (Design)}

Pada tahap ini disusun draft LKPD yang dikembangkan sesuai dengan hasil analisis kebutuhan sebelumnya. Secara garis besar LKPD yang dikembangkan terdiri dari 3 bagian, yaitu bagian pembuka, bagian isi dan bagian penutup. Bagian pembuka terdiri dari halaman sampul, halaman identitas, dan halaman pendukung lainnya. Bagian isi terdiri dari halaman peta konsep, standar isi, ketercapaian tu- 
juan pembelajaran setiap kegiatan, dan kegiatan pembelajaran. Bagian penutup terdiri dari rangkuman, daftar pustaka, biodata penulis, lembar jawab dan kertas praktik, dan halaman sampul belakang.

\section{Tahap Pengembangan (development)}

Setiap kegiatan pada LKPD disusun sesuai dengan sintaks model pembelajaran MMP yaitu pendahuluan(review), pengembangan (development), kerja kooperatif (team), kerja madiri (seatwork) dan penutup (cover) (Rahmiati \& Fahrurrozi, 2016). Pada pendahuluan, peserta didik diajak untuk mengingat kembali materi sebelumnya yang terkait dengan materi yang akan dibahas. Tahap pengembangan memuat kegiatan mengembangkan materi sebelumnya guna memperoleh materi baru. Pada tahap ini dilaksanakan melalui proses diskusi. Tahap kerja kooperatif berisi rangkaian soal-soal berdasarkan materi yang telah dikembangkan dan diselesaikan dalam kerja kelompok. Menyelesaikan rangkaian soal secara mandiri dilaksanakan pada tahap kerja mandiri. Tahap penutup merupakan tahap akhir dimana pada tahap ini peserta didik membuat rangkuman materi yang telah diperoleh dari berbagai kegiatan sebelumnya.

Kegiatan pertama membahas tentang luas permukaan kubus. Pada tahap pendahuluan diberikan sebuah gambar kubus kemudian peserta didik diajak untuk mengingat kembali tentang definisi, sifat-sifat, dan unsur-unsur kubus sebagai materi prasyarat. Tahap pengembangan, diawali dengan kegiatan peserta didik membuat berbagai bentuk jaring-jaring kubus kemudian diberikan serangkaian kegiatan yang harus didiskusikan sehingga ditemukan konsep luas permukaan kubus. Selanjutnya melalui tahap kerja kooperatif, peserta didik secara berkelompok mendiskusikan soal-soal kontekstual. Pada tahap kerja mandiri, diberikan berbagai persolan yangterkait dengan luas permukaan kubus yang harus dikerjakan sendiri-sendiri. Pada tahap penutup, diberikan petunjuk-petunjuk untuk membantu peserta didik menyimpulkan atau membuat rangkuman dari kegiatan sebelumnya. Tahap MMP seperti pada kegiatan pertama ini juga dilakukan untuk kegiatan ke dua dan ketiga.

Tata bahasa yang digunakan disesuaikan dengan tingkat kemampuan peserta didik agar mudah dipahami secara mandiri oleh peserta didik. LKPD dilengkapi dengan gambar-gambar yang menarik dan dapat membantu peserta didik dalam memahami konsep materi yang disajikan.Hal ini sangat diperlukan karena LKPD digunakan peserta didik dalam pembelajaran online. Dimana dalam pembelajaran tersebut peserta didik tidak bertatap muka secara langsung dengan gurunya. LKPD inilah yang menjadi penghubung antara guru dan peserta didik dalam proses memahami materi yang diberikan. 


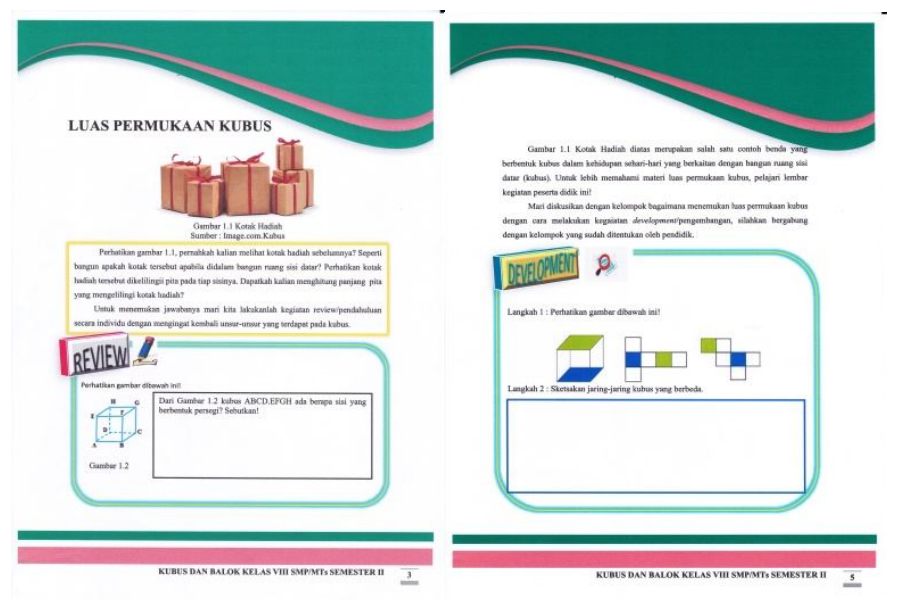

Gambar 1. LKPD dengan sintaks MMP

\section{Tahap Implementasi (implementation)}

LKPD diimplementasikan pada proses pembelajaran di SMPN 3 Jetis dengan subjek penelitian Kelas VIIIB dan VIIID, jumlah peserta didik Kelas VIIIB sebanyak 26 peserta didik dan VIIID sebanyak 30 peserta didik. Pembelajaran dilakukan secara online melalui whatsapp group, google meet, dan google classroom.

Peserta didik sangat antusias dalam melaksanakan tugasnya yang telah disiapkan melalui LKPD. Setiap tahapan kegiatan dilalui oleh peserta didik dengan aktif. Peserta didik yang selama ini terlihat kurang aktif dikelas aktif bertanya dan memberikan pendapatnya dalam pembelajaran online. Hal ini dapat terjadi karena melalui LKPD yang diberikan peserta didik telah mengetahui kegiatan-kegiatan apa saja yang harus mereka lakukan. Mereka juga dibimbing untuk mengasah pola pikirnya untuk menemukan sendiri konsep dari materi yang sedang dipelajari. Hal ini juga didukung karena pembelajaran secara online peserta didik tidak bertatap muka secara langsung seperti di dalam kelas sehingga peserta didik menjadi lebih berani dan dapat menghilangkan rasa malunya.

\section{Tahap Evaluasi (Evaluation)}

\section{Kevalidan LKPD}

Menilai suatu bahan ajar apakah memiliki validitas isi yang tinggi dapat dilakukan oleh para ahli (Lestari \& Andriani, 2019). Dalam penelitian ini LKPD dinilai oleh ahli materi yang merupakan dosen pengampu mata kuliah geometri dan ahli bahan ajar yang merupakan dosen pengampu mata kuliah pengebangan bahan ajar. Kedua ahli tersebut merupakan dosen pada Program Studi Pendidikan Matematika Universitas PGRI Yogyakarta. Berikut diberikan hasil penilaian dari ahli materi dan ahli bahan ajar. 
Tabel 3. Penilaian Ahli Materi

\begin{tabular}{lcc}
\hline \multicolumn{1}{c}{ Aspek } & Penilaian & Kriteria \\
\hline Kelayakan Isi & 3,50 & Sangat Valid \\
Kelayakan Bahasa & 3,33 & Valid \\
Kelayakan Materi & 3,63 & Sangat Valid \\
Total & 3,50 & Sangat Valid \\
\hline
\end{tabular}

Tabel 4. Penilaian Ahli Bahan Ajar

\begin{tabular}{lcc}
\hline \multicolumn{1}{c}{ Aspek } & Penilaian & Kriteria \\
\hline Kelayakan Bahasa & 3,22 & Valid \\
Kegrafikan & 3 & Valid \\
Total & 3,12 & Valid \\
\hline
\end{tabular}

Ahli materi memberikan penilaian sangat valid terhadap materi yang disajikan dalam LKPD. Isi materi telah sesuai dengan Standar Kompetensi dan Kompetensi Dasar untuk kelas VIII SMP. Materi yang diberikan juga sudah sesuai. Dari segi bahasa yang digunakan juga menarik dan mudah dipahami oleh peserta didik. Ahli media juga memberikan penilain valid untuk LKPD yang dikembangkan. Komposisi gambar dan huruf sangat menarik dan menarik perhatian peserta didik untuk membacanya. Pembagian setiap langkah model MMP juga jelas pada LKPD yang dikembangkan. Semua unsur-unsur LKPD juga telah terpenuhi.

\section{Kepraktisan LKPD}

Penilaian aspek kepraktisan LKPD dilakukan oleh pendidik dan peserta didik sebagai pengguna LKPD dengan mengisi lembar angket respon. Angket respon ini diisi oleh pendidik dan peserta didik setelah menggunakan LKPD yang dikembangkan dalam proses pembelajaran. Berikut ini hasil penilaian aspek kepratisan LKPD.

Tabel 5. Data Hasil Penilaian Respon Pendidik Terhadap LKPD

\begin{tabular}{lcc}
\hline \multicolumn{1}{c}{ Aspek } & Skor RataRata & Kriteria \\
\hline Kelayakan Isi & 3,70 & Sangat Praktis \\
Kesesuaian Bahasa & 3,62 & Sangat Praktis \\
Kegrafikan & 3,58 & Sangat Praktis \\
Rata-rata & 3,63 & Sangat Praktis \\
\hline
\end{tabular}


Tabel 6. Data Angket Respon Peserta Didik Terhadap LKPD

\begin{tabular}{lccc}
\hline \multicolumn{1}{c}{ Aspek } & Penilaian & Kriteria \\
\hline Kesesuaian Penggunaan $\quad$ Bahasa & dan & 3,55 & Sangat Praktis \\
$\begin{array}{l}\text { Kalimat serta tampilan LKPD } \\
\text { Penggunaan LKPD Dalam Pembelajaran }\end{array}$ & 3,50 & Sangat Praktis \\
Kesesuaian Materi LKPD & 3,51 & Sangat Praktis \\
\hline Rata - rata & 3,52 & Sangat Praktis \\
\hline
\end{tabular}

LKPD yang dikembangkan sangat praktis digunakan dalam pembelajaran matematika khususnya materi bangun ruang sisi datar kubus dan balok. Materi yang disajikan sesuai dengan Standar Kompetensi dan Kompetensi Dasar. Bahasa yang digunakan mudah dipahami dan tata letak gambar dan huruf juga sangat menarik. Kalimat yang digunakan dalam LKPD sangat mudah dipahami dan tidak memberikan penafsiran ganda.

Sintak MMP pada LKPD sangat jelas sehingga sangat membantu pendidik dalam meningkatkan pemahaman konsep peserta didik. Langkah-langkah yang harus dikerjakan oleh peserta didik dalam LKPD ini untuk memahami konsep sangat jelas. Pembelajaran terasa tidak membosankan. Hal ini sejalan dengan pendapat Aufa et al. (2021) dimana peserta didik merasa senang dengan komponen pembelajaran melalui model MMP. Keterbatasan kuota dan sinyal dapat sedikit teratasi dengan menggunakan LKPD ini karena dengan menggunakan LKPD ini peserta didik menjadi lebih mandiri tidak selalu bertanya dengan pendidik yang dapat mengahbiskan lebih banyak kuota.

\section{Keefektifan LKPD}

Keefektifan LKPD menggunakan Model Pembelajaran MMP untuk memfasilitasi kemampuan pemhaman konsep matematika peserta didik kelas VIII ditinjau dari hasil tes pemahaman konsep materi bangun ruang sisi datar kubus dan balok yang terdiri dari 4 soal uraian dengan memuat 7 indikator pemahaman konsep. Hasil tes tersebut dapat dilihat sebagai berikut. 
Tabel 7. Hasil Analisis Indikator Pemahaman Konsep

\begin{tabular}{lcc}
\hline \multicolumn{1}{c}{ Presentase Setiap Aspek } & Nilai & Kriteria \\
\hline Menyatakan ulang sebuah konsep & 69,0 & Baik \\
$\begin{array}{l}\text { Mengklasifikasi obyek-obyek } \\
\text { Memberi contoh dan non-contoh dari konsep }\end{array}$ & 83,5 & Sangat Baik \\
$\begin{array}{l}\text { Menyajikan konsep dalam berbagai bentuk representasi } \\
\text { matematis }\end{array}$ & 83,2 & Sangat Baik \\
$\begin{array}{l}\text { Mengembangkan syarat perlu atau syarat cukup suatu } \\
\text { konsep }\end{array}$ & 80,8 & Sangat Baik \\
$\begin{array}{l}\text { Menggunakan, memanfaatkan, dan memilih prosedur } \\
\text { atau operasi tertentu }\end{array}$ & 76,9 & Baik \\
$\begin{array}{l}\text { Mengaplikasikan konsep atau alogaritma pemecahan } \\
\text { masalah }\end{array}$ & 72,8 & Baik \\
\hline Rata - rata & 73,8 & Baik
\end{tabular}

Hasil analisis tujuh indikator pemahaman konsep didapatkan total hasil dari tiap indikator 78,3 dari skor maksimal 100 dengan kriteria kualitatif yaitu baik. Hal ini menunjukan bahwa peserta didik dapat memahami setiap indikator pemahaman konsep pada setiap butir soal. Sehingga dapat dinyatakan bahwa LKPD yang dikembangkan efektif digunakan dalam proses pembelajaran. Sejalan dengan pendapat Wahyuni et al. (2020), kegiatan yang diberikan pada setiap tahapannya memberikan kesempatan kepada peserta didik untuk lebih mnengembangkan ide-ide kreatifnya. Hal ini menyebabkan peserta didik dapat memahami konsep materi yang diberikan.

Hasil penelitian ini sejalan juga sejalan dengan hasil penelitian pengembangan yang dilakukan oleh Rais (2017) yang menyatakan bahwa perangkat pembelajaran matematika dengan model MMP layak dijadikan rujukan dalam pembelajaran matematika di sekolah. LKPD merupakan salah satu perangkat pembelajaran yang digunakan dalam kegiatan pembelajaran di sekolah.

\section{Kesimpulan}

Pengembangan Lembar Kegiatan Peserta Didik (LKPD) menggunakan model pembelajaran Missouri Mathematics Project (MMP) pada materi bangun ruang sisi datar kubus dan balok yang digunakan dalam pembelajaran online layak (valid, praktis dan efektif) untuk digunkan dalam pembelajaran. Aspek kevalidan diperoleh dari penilaian ahli materi dan ahli media. Ahli materi memberikan skor penilaian 3,50 (sangat valid) dan ahli media memberikan skor penilaian 3,12 (valid). Dari aspek kepraktisan, pendidik mendapat skor 3,69 (sangat praktis) dan peserta 
didik memberikan skor penilain 3,52 (sangat praktis). Aspek keefektifan LKPD untuk memfasilitasi pemahaman konsep peserta didik dilihat dari skor tes yang dilakukan oleh peserta didik setelah proses pembelajaran menggunakan LKPD. Rata-rata skor tes peserta didik adalah 73, 8 yang berarti LKPD praktis digunakan dalam pembelajaran.

\section{Ucapan Terimakasih}

Terima kasih penulis ucapkan kepada Universitas PGRI Yogyakarta dan SMPN 3 Jetis yang telah mendukung terlaksananya penelitian ini.

\section{Daftar Pustaka}

Anugrahana, A. (2020). Hambatan, Solusi dan Harapan: Pembelajaran Daring Selama Masa Pandemi Covid-19 Oleh Guru Sekolah Dasar. Scholaria: Jurnal Pendidikan Dan Kebudayaan, 10(3), 282-289. https:/ / doi.org/ 10.24246/ j.js.2020.v10.i3.p282-289

Aufa, N., Zubainur, C. M., \& Munzir, S. (2021). Pengembangan Perangkat Pembelajaran Model Missouri Mathematics Project (MMP) Berbantuan Software Geogebra Untuk Meningkatkan Pemahaman Konsep Siswa. JIP Jurnal Inovasi Pendidikan, 1(11).

Basori, B. (2014). Efektifitas Komunikasi Pembelajaran Online Dengan Menggunakan Media E-Learning Pada Perkuliahan Body Otomotif. Jurnal Ilmiah Pendidikan Teknik Dan Kejuruan, 7(2), 39-45. https:/ / doi.org/ 10.20961/jiptek.v7i2.12722

Devita Yohanie, D., \& Samijo. (2019). Pengembangan Modul Berdasarkan Pemecahan Masalah Polya Pada Mata Kuliah Analisis Vektor. Jurnal Math Educator Nusantara (JMEN), 5(2), 172-181.

Dewi, R., Jaya, W. S., \& Rahmawati, F. (2019). Pengaruh Model Pembelajaran Missouri Mathematics Project (MMP) Terhadap Kemampuan Pemecahan Masalah Matematika Siswa. Jurnal Mahasiswa Pendidikan Matematika (JMPM), 1(2), 1-11.

Fauziah, A., \& Sukasno, S. (2015). Pengaruh Model Missouri Mathematics Project (MMP) Terhadap Kemampuan Pemahaman Dan Pemecahan Masalah Matematika Siswa SMAN I Lubuklinggau. Infinity Journal, 4(1), 10-21. https:/ / doi.org/ 10.22460/ infinity.v4i1.67

Firdaus. (2020). Implementasi Dan Hambatan Pada Pembelajaran Daring Di Masa Pandemi Covid 19. Utile: Jurnal Kependidikan, 6(2), 220-225. https:/ / doi.org/ 10.37150/ jut.v6i2.1009

Herliandry, L. D., Nurhasanah, Suban, M. E., \& Heru, K. (2020). Pembelajaran Pada 
Masa Pandemi Covid-19. Jurnal Teknologi Pendidikan, 22(1), 65-70. https:/ / doi.org/ https:/ / doi.org/ 10.21009/ jtp.v22i1.15286

Lestari, F., \& Gita Andriani, D. (2019). Validasi Modul Berbasis Literasi Pada Matakuliah Statistika Matematika. Jurnal Math Educator Nusantara (JMEN), 5(1), 36-42.

Ningsih, S. C., \& Sunanti, T. (2020). Developing Student Worksheet for Learning Independence. 2nd UPY Internasional Conference On Applied Science and Education 2020 (UPINCASE 2).

Rahmiati, R., \& Fahrurrozi, F. (2016). Pengaruh Pembelajaran Missouri Mathematics Project (MMP) Terhadap Kemampuan Pemecahan Masalah Matematika. Jurnal Pendidikan Matematika, 10(2), 1-12. https:// doi.org/ 10.22342/jpm.10.2.3634.75-86

Rais, D. (2017). Pengembangan Perangkat Pembelajaran Matematika Berbasis Missouri Mathematics Project untuk Meningkatkan Kemampuan Komunikasi Matematis Peserta Didik Kelas X SMA/ MA. JNPM (Jurnal Nasional Pendidikan Matematika), 1(2), 189-205. https:/ / doi.org/ 10.33603/jnpm.v1i2.473

Sadikin, A., \& Hamidah, A. (2020). Pembelajaran Daring di Tengah Wabah Covid-19. Biodik, 6(2), 214-224. https:/ / doi.org/ 10.22437/ bio.v6i2.9759

Saefulmulah, R. M. I., \& M Saway, M. H. (2020). Hambatan-Hambatan Pada Pelaksanaan Pembelajaran Daring Di SMA Riyadhul Jannah Jalancagak Subang. Nusantara: Jurnal Pendidikan Dan Ilmu Sosial, 2(November), 393-404. Retrieved from https:/ / ejournal.stitpn.ac.id/index.php/ nusantara

Sun, L., Tang, Y., \& Zuo, W. (2020). Coronavirus pushes education online. Nature Materials, 19(6), 687. https:/ / doi.org/ 10.1038/ s41563-020-0678-8

Surat Edaran Nomor 4 Tahun 2020 Tentang Pelaksanaan Kebijakan Pendidikan Dalam Masa Darurat Penyebaran Coronavirus Disease (Covid-19). , (2020).

Susilo, A., Rumende, C. M., Pitoyo, C. W., Santoso, W. D., Yulianti, M., Herikurniawan, H., Yunihastuti, E. (2020). Coronavirus Disease 2019: Tinjauan Literatur Terkini. Jurnal Penyakit Dalam Indonesia, 7(1), 45-67. https:// doi.org/ 10.7454/jpdi.v7i1.415

Tiasto, R. H., \& Arliani, E. (2015). Model Pembelajaran Missouri Mathematics Project dengan Metode Two Stay Two Stray Efektivitasnya Terhadap Kemampuan Pemecahan Masalah Matematika Siswa Kelas VII SMPN 1 tawangmangu. Seminar Nasional Matematika Dan Pendidikan Matematika UNY 2015, 5(4), 1191-1198. Retrieved from http:/ / journal.student.uny.ac.id/ ojs/ index.php/ pmath/ issue/ view/ 440 Umbaryati. (2016). Pentingnya LKPD pada Pendekatan Scientific Pembelajaran 
Matematika. Prosiding Seminar Nasional Matematika IX 2015 Universitas Negeri Semarang, 217-225.

Wahyono, P., Husamah, H., \& Budi, A. S. (2020). Guru profesional di masa pandemi

COVID-19: Review implementasi, tantangan, dan solusi pembelajaran daring.

Jurnal Pendidikan Profesi Guru, 1(1), 51-65.

https:/ / doi.org/ 10.22219/ JPPG.V1I1.12462

Wahyuni, R., Efuansyah, \& Sukasno. (2020). Developing Student Worksheet Based

On Missouri Mathematics Project Model By Using Think-Talk-Write Strategy Of Class VIII. Infinity Journal of Mathematics Education. P-ISSN 2089-6867. E-ISSN 2460-9285, 9(1), 81-92.

Widodo, S. (2017). Pengembangan Lembar Kegiatan Peserta Didik (LKPD) berbasis Pendekatan Saintifik untuk Meningkatkan Keterampilan Penyelesaian Masalah Lingkungan Sekitar Peserta Didik di Sekolah Dasar. JPIS Jurnal Pendidikan Ilmu Sosial. E-ISSN 2540-7694. P-ISSN 0854-5251, 26(2), 189-204.

Widyoko, S. E. P. (2015). Teknik Penyusunan Instrumen Penelitian. Pustaka Pelajar. 